\title{
Wild dengue virus types 1, 2 and 3 viremia in rhesus monkeys
}

\section{MS Freire, RS Marchevsky LFC Almeida, AMY Yamamura, EC Caride, PA Brindeiro, MCA Motta, RMR Nógueira ${ }^{*}$, CF Kubelka ${ }^{*}$, MC Bonaldo ${ }^{* *}$, R Galler**/+}

Instituto de Tecnologia em Imunobiológicos-Fiocruz *Departamento de Virologia, ** Departamento de Bioquimica e Biologia Molecular, Instituto Oswaldo Cruz-Fiocruz, Av. Brasil 4365, 21040-900 Rio de Janeiro, RJ, Brasil

Among the flaviviruses, dengue, with its four serotypes, has spread throughout the tropics. The most advanced vaccines developed so far include live attenuated viruses, which have been tested in humans but none has been licensed. Preclinical testing of dengue vaccine candidates is performed initially in mice and in nonhuman primates. In the latter the main criteria used to assay protection are neutralizing antibodies elicited by the vaccine candidate and the magnitude and duration of peripheral viremia upon challenge of previously immunized animals. Towards the identification of wild-type viruses that could be used in challenge experiments a total of 31 rhesus monkeys were inoculated subcutaneously of wild dengue types 1, 2, and 3 viruses. The viremia caused by the different viruses was variable but it was possible to identify dengue viruses useful as challenge strains.

Key words: flaviviruses - dengue virus - infectivity - rhesus monkeys

The genus Flavivirus consists of 70 serologically crossreactive viruses, several of which cause human illnesses, the most important being yellow fever (YF), Japanese encephalitis (JE), and dengue (DENV) with its four serotypes. DEN viruses have spread throughout the tropics and an increasing frequency of the more severe forms of dengue fever (DF): dengue hemorrhagic fever (DHF) and dengue shock syndrome (DSS) is being observed (Gubler 2004). Approved vaccines are available only for YF virus, the attenuated live 17D virus (Monath 2003) and for tick-borne encephalitis (TBE) virus and JE virus, both as inactivated viruses (Monath \& Heinz 1996). For DENV, live attenuated candidate vaccines have been developed using serial passages in cultured vertebrate cells and tested in humans (Bhamarapravatai \& Yoksan 2000, Edelman et al. 2003, Sabchareon et al. 2002, 2004, Sun et al. 2003) but so far none has been licensed.

Preclinical testing of dengue vaccine candidates has been usually carried out initially in a mouse model (Bente \& Rico-Hesse 2006) in which protection against challenge with a mouse-adapted neurovirulent virus is the main criteria for efficacy. The next step for testing a candidate vaccine is the study of its immunogenicity in a nonhuman primate model. Although some hallmarks of dengue severe syndromes have been described (Halstead et al. 1973a,b), it is widely accepted that the main parameters to be consid-

Financial support: PADCT (0442-98), CNPq (50.1526/2003-0; 472809/2003-2), PDTIS/Fiocruz (RVR10), Papes/Fiocruz (0250.250.156), Millennium Institute for Vaccine Technology and Development

+Corresponding author: rgaller@bio.fiocruz.br

Received 9 November 2006

Accepted 6 February 2007 ered are neutralizing antibodies induced by the vaccine candidate and the magnitude and duration of peripheral viremia upon challenge of previously immunized animals (Halstead \& Marchette 2003, Raviprakash et al. 2003, 2006, Eckels et al. 2003, Hanley et al. 2004, Guirakhoo et al. 2004, Blaney et al. 2005, Sun et al. 2006). In our efforts to develop a live attenuated dengue vaccine based on chimeric VF 17D viruses (Caufour et al. 2001, Mateu et al. 2007) we needed to establish a nonhuman primate model to test the protective capability of the recombinant viruses. Here, we describe the infectivity of wild-type dengue types 1,2 , and 3 viruses to rhesus monkeys and discuss their use in testing the efficacy of dengue vaccines in general.

\section{MATERIALS AND METHODS}

Cells - Vero cells (ATCC, CCL 81) were maintained in Medium 199 with Earle's salts (E199), buffered with sodium bicarbonate and supplemented with $5 \%$ fetal bovine serum (FBS) and antibiotics. C6/36 cells were grown in Leibovitz's L-15 medium (Gibco) supplemented with $5 \%$ FBS and antibiotics.

\section{Viruses}

DENV-1 60305 - It was isolated during an epidemic on 1998 in Pinheiral (state of Rio de Janeiro) from a human case of DF by passaging thrice in C6/36 cells and belongs to genotype I or the Americas/Africa genogroup (Rico-Hesse 2003). Four blind passages were carried out in Vero cells until cytopathic effect (CPE) and its ability to plaque was well established. The working seed stock was prepared-in Vero cells with a titer of $7.1 \log _{10}$ $\mathrm{PFU} / \mathrm{ml}$.

DENV-1 16007/V and 16007/C - The 16007 virus belongs to genotype II (Gonçalvez et al. 2002) or the Thailand genogroup and was isolated from serum of a DHF case in the Thailand by passaging 3 times in BSC-1 cells, 7 times in LLC-MK $\mathrm{M}_{2}$ and two more in Toxorynchites amboinensis mosquitoes (Halstead \& Marchette 2003). In Bio-Manguinhos it was passaged 3 times in 
C6/36, one in Vero cells for the preparation of the working seed (16007/V; $\left.6.9 \log _{10} \mathrm{PFU} / \mathrm{ml}\right)$ and an additional passage in $\mathrm{C} 6 / 36$ for preparation of the $16007 / \mathrm{C}$ stock $\left(5.8 \log _{10} \mathrm{PFU} / \mathrm{ml}\right)$. Both stocks contained viruses capable of plaquing on Vero cells.

$D E N V$-2 40247 - Originated from a human case of DHF in Niterói, state of Rio de Janeiro (Nogueira et al. 1991). This virus belongs to the group of DENV-2 Southeast Asian genotype viruses more recently introduced in the Americas (Rico-Hesse et al. 1997). It was isolated in C6/36 cells and used as the fourth passage in this cell type. The dose was calculated after serial dilution and plaquing on Vero cells (6.2 $\left.\log _{10} \mathrm{PFU} / \mathrm{ml}\right)$.

DENV-2 44/2 strain - Originated from an isolate (56344; Vitória, state of Espírito Santo; Miagostovich et al. 2003) of a human case of DF. This virus belongs to the group of DENV-2 Southeast Asian genotype viruses (genotype III Jamaica genotype; Rico-Hesse et al. 1997, Miagostovich et al. 2003). It was isolated in C6/36 cells and at its third passage it was plaque purified in Vero cells. Three plaque purifications were carried out. The selected 44/2 clone virus produces uniformly sized plaques. A working seed was prepared with a titer of 7.5 $\log _{10} \mathrm{PFU} / \mathrm{ml}$.

DENV-3 H87 - It is the prototype DENV-3 isolated in 1956 from a human case of DHF in the Phillipines (Hammon et al. 1960) and belongs to Southeast Asia/ South Pacific genotype. The exact passage number is unknown. At Fiocruz it was propagated by 3 serial passages in suckling mouse brain and 10 serial passages in Vero cells. The working seed lot virus was prepared and titrated in Vero cells $\left(7.1 \log _{10} \mathrm{PFU} / \mathrm{ml}\right)$.

$D E N V-316562$ - It was isolated from sera of a DHF case in Phillipines. It belongs to genotype II (Southeast Asia/South Pacific; Rico-Hesse 2003). The virus was propagated by serial passages in BSC-1 (3 times) cells, in LLC-MK 2 (4 times) and two more in T. amboinensis mosquitoes (Halstead \& Marchette 2003). It was further passaged in C6/36 cells another 5 times. In BioManguinhos it was passaged twice in Vero cells for the preparation of the working seed $\left(7.3 \log _{10} \mathrm{PFU} / \mathrm{ml}\right)$.

$D E N V$-3 74886 - It was isolated in 2002 from the liver of a fatal human case of DSS in Nova Iguaçú, state of Rio de Janeiro, through C6/36 cell passages. It belongs to subtype III (Sri Lanka/India), which is the genogroup circulating in the American Continent (RicoHesse 2003, De Simone et al. 2004). A total of 8 passages in C6/36 cells were carried out from the serum until the preparation of the working seed. The virus does not plaque in Vero cells although culture supernatant and monolayer were positive in RT-PCR assays. It was titered in $\mathrm{C} 6 / 36$ cells $\left(7.8 \log _{10} \mathrm{TCID}_{50}\right.$ ).

Virus titration - All virus stocks (except for DENV3 74886) were titered by plaque formation on Vero cell monolayers $\left(60,000\right.$ cells $\left./ \mathrm{cm}^{2}\right)$ using 6-well plates and carboxymethyl-cellulose as overlay. After 7-10 days in- cubation at $37^{\circ} \mathrm{C}, 5 \% \mathrm{CO}_{2}$ and $100 \%$ relative humidity, the cell cultures were fixed with formalin and stained with crystal violet.

Infection of rhesus monkeys with wild type DV Studies were carried out using a protocol revised and approved by the Institutional Animal Care and Use Committee (CEUA/Fiocruz PO112/02). All rhesus monkeys (Macaca mulatta) came from the colony maintained by the Primatology Department (Cecal/Fiocruz), Rio de Janeiro, Brazil and were housed in individual stainlesssteel cages, in climate-controlled room $\left(21 \pm 1^{\circ} \mathrm{C}\right.$ and $55 \pm 5 \%$ relative humidity). They were fed with commercial monkey chow, supplemented with fruits and vegetables. Water was available ad libitum. All monkeys were shown to be negative for DENV-1, -2 , and -3 types and YF by plaque reduction neutralization tests (PRNT).

The monkeys were inoculated subcutaneously on the anterior surface of the left forearm with $0.5 \mathrm{ml}$ of viral suspension containing $10^{5} \mathrm{TCID}_{50}(\mathrm{DENV}-3$ 74886) or $10^{5} \mathrm{PFU}$ (all other viruses).

Dengue type 1 - A total of 11 monkeys, 5 males and 6 females, weighing from $3300 \mathrm{~g}$ to $14,220 \mathrm{~g}$ were inoculated with wild type DENV-1 viruses, 5 with strain 60305 (H17, I8, P4, Q62, U73), and 3 with 16007/V (V stands for Vero cell-passaged virus; E10, O32, V23). Another 3 (M12, R51, V21) animals were inoculated with DENV-1 16007/C (C means C6/36-passaged virus).

Dengue type 2 - A total of 10 monkeys, all males, weighing from $5340 \mathrm{~g}$ to $7280 \mathrm{~g}$ were inoculated with wild type DENV-2 viruses, 5 with strain 44/2 (P11, P21, $\mathrm{P} 25, \mathrm{P} 33, \mathrm{O} 65)$ and 5 with strain 40247 (O49, P17, P37, P47, P57).

Dengue type 3 - Eleven monkeys, 2 males and 9 females, weighing from $5400 \mathrm{~g}$ to $10,700 \mathrm{~g}$ were inoculated with wild type DENV-3 viruses, 5 with H87 virus (E19, N20, $\mathrm{P} 24, \mathrm{P} 44,123)$, and 3 with $16562 / \mathrm{V}$ (V stands for Vero cell-passaged virus; F2, M6, S34) and 3 with 74886/C (for C6/36-passaged virus; M50, N44, O48).

Viremia - Monkey serum samples (day 1-13 postinoculation) were titrated on monolayers of Vero cells $\left(10^{5} \mathrm{cells} / \mathrm{cm}^{2}\right)$. One hundred microliters of serum, undiluted or diluted $1 / 3$ and $1 / 30$ were inoculated in each well of a 6-well plates, with 4 wells per dilution. Vero cell monolayers were overlaid with $3.5 \%$ carboxymethylcellulose. After incubation at $37^{\circ} \mathrm{C}$ in $5 \% \mathrm{CO}_{2}$ atmosphere for 7-10 days, the monolayers were fixed with $10 \%$ formalin, stained with crystal violet and plaques counted.

\section{RESULTS}

Infectivity of dengue type 1 viruses - Five rhesus monkeys were inoculated with a single subcutaneous dose of $5.0 \log _{10}$ PFU/ml of DENV-1 virus 60305 and 6 monkeys with 16007 virus, being 3 with the Vero cellpassaged virus and 3 with virus propagated in C6/36 cells. Monkeys were bled from days 2 through 10 for 60305 virus and from day 2 post-inoculation (p.i.) until day 13 for 16007 viruses. Viremia was assayed by plaque titration on Vero cell monolayers and the results are shown 
in Table I. Only days in which any viremia could be detected are displayed.

The DENV-1 60305 virus induced viremia in 4 out of 5 rhesus monkeys with duration from 1 to 8 days (mean duration of 3 days/animal) and a mean titer of $1.2 \pm 0.4$ $\log _{10} \mathrm{PFU} / \mathrm{ml}$. However, the DENV-1 16007 viruses caused higher viremia with longer duration. The 16007 virus prepared in Vero cells showed a mean duration of 7 days/animal and was present in all 3 rhesus monkeys yielding a mean peak titer of $1.9 \pm 0.6 \log _{10} \mathrm{PFU} / \mathrm{ml}$. The 16007 virus prepared in C6/36 cells, showed somewhat reduced viremia as compared to its counterpart prepared in Vero cells as mean duration of viremia was 4 days/animal. Mean peak titer was not significantly different $\left(1.9 \pm 0.2 \log _{10} \mathrm{PFU} / \mathrm{ml}\right)$.

Infectivity of dengue type 2 viruses - Five rhesus monkeys were inoculated with DENV-2 44/2 virus and another 5 animals with 40247 virus. Monkeys were bled at day 0 and thereafter for 10 consecutive days. All 5 animals that received the DENV-2 44/2 showed viremia whereas four out of 5 animals that received the DENV-2 40247 did so (Table II). For 44/2 virus the viremia was detectable from days 1 to 8 in 3 animals and days 1 through 6 in the remaining two with an average duration period of 6.6 days/animal. The 40247 virus could only be detected in the sera of monkeys between the 4th and 7 th days after inoculation with an average duration period of 2.2 days/animal. The magnitude of viremia between the viruses was also different: 0.9 to $2.9 \log _{10} \mathrm{PFU} /$ $\mathrm{ml}$ for $44 / 2$ (mean peak titer of $2.7 \log _{10} \mathrm{PFU} / \mathrm{ml}$ ) and 1.2 to $3.6 \log _{10} \mathrm{PFU} / \mathrm{ml}$ for 40247 virus (mean peak titer of $\left.3.2 \log _{10} \mathrm{PFU} / \mathrm{ml}\right)$.

Infectivity of dengue type 3 viruses - We have inoculated 5 rhesus monkeys with DENV-3 virus H87, 3 animals with Vero cell-passaged 16562 virus and another 3 with 74886 virus propagated in C6/36 cells. Monkeys were bled from days 2 through 10 for $\mathrm{H} 87$ virus and from day 2 pi until day 13 for 16562 and 74886 viruses. Viremia was assayed by plaque titration on Vero cell monolayers and the results are shown in Table III.

The DENV-3 H87 virus induced viremia in all 5 rhesus monkeys with duration from 3 to 6 days (mean duration of 4.4 days/animal) and a mean titer of approximately $2.0 \log _{10} \mathrm{PFU} / \mathrm{ml}$. In contrast none of the other two DENV-3 viruses used induced any detectable viremia after plaque assay on Vero cells. We have analyzed vire-

TABLE I

Wild-type dengue 1 viremia in rhesus monkeys

\begin{tabular}{|c|c|c|c|c|c|c|c|c|c|c|c|}
\hline \multirow[t]{2}{*}{ Virus } & \multirow[t]{2}{*}{ Monkey } & \multicolumn{9}{|c|}{ Viremia $\left(\log _{10} \mathrm{PFU} / \mathrm{ml}\right)$} & \multirow[b]{2}{*}{ Mean peak titer } \\
\hline & & 3 & 4 & 5 & 6 & 7 & 8 & 9 & 10 & Duration (days) & \\
\hline & H17 & $<0.4$ & $<0.4$ & $<0.4$ & $<0.4$ & $<0.4$ & $<0.4$ & 0.9 & $<0.4$ & 1 & \\
\hline DENV-1 & I8 & 0.4 & 0.9 & 1.0 & 1.0 & 0.9 & 1.4 & 1.6 & 0.4 & 8 & \\
\hline \multirow[t]{3}{*}{60305} & P4 & $<0.4$ & $<0.4$ & $<0.4$ & $<0.4$ & $<0.4$ & $<0.4$ & $<0.4$ & $<0.4$ & 0 & $1.2 \pm 0.4$ \\
\hline & Q62 & $<0.4$ & $<0.4$ & $<0.4$ & $<0.4$ & $<0.4$ & 0.7 & 0.9 & $<0.4$ & 2 & \\
\hline & U73 & $<0.4$ & $<0.4$ & $<0.4$ & $<0.4$ & 0.7 & 1.2 & 1.4 & 1.3 & 4 & \\
\hline \multirow[t]{2}{*}{ Virus } & Monkey & \multicolumn{9}{|c|}{ Viremia $\left(\log _{10} \mathrm{PFU} / \mathrm{ml}\right)$} & \\
\hline & & 4 & 5 & & 6 & 7 & 8 & 9 & 10 & Duration (days) & Mean peak titer \\
\hline DENV-1 & E10 & 1.4 & 1.4 & & 1.6 & 1.9 & 2.1 & 1.8 & 1.3 & 7 & \\
\hline \multirow[t]{2}{*}{$16007 / \mathrm{V}$} & V23 & 1.2 & 1.9 & & 2.1 & 2.3 & 2.4 & 1.7 & 1.4 & 7 & $1.9 \pm 0.6$ \\
\hline & $\mathrm{O} 32$ & 1.0 & 0.7 & & 0.9 & 0.4 & 1.2 & 1.4 & 1.2 & 7 & \\
\hline DENV-1 & R51 & $<0.4$ & 1.7 & & 1.9 & 1.8 & 1.6 & 1.0 & $<0.4$ & 5 & \\
\hline \multirow{2}{*}{$16007 / \mathrm{C}$} & V21 & $<0.4$ & $<0.4$ & & 1.3 & 1.8 & 1.9 & $<0.4$ & $<0.4$ & 3 & $1.9 \pm 0.2$ \\
\hline & M12 & $<0.4$ & 0.7 & & 1.7 & 1.5 & 1.0 & $<0.4$ & $<0.4$ & 4 & \\
\hline
\end{tabular}

TABLE II

Wild-type dengue 2 viremias in rhesus monkeys

\begin{tabular}{|c|c|c|c|c|c|c|c|c|c|c|c|}
\hline \multirow[t]{2}{*}{ Virus } & \multirow[t]{2}{*}{ Monkey } & \multicolumn{9}{|c|}{ Viremia $\left(\log _{10} \mathrm{PFU} / \mathrm{ml}\right)$} & \multirow[b]{2}{*}{ Mean peak titer } \\
\hline & & 1 & 2 & 3 & 4 & 5 & 6 & 7 & 8 & Duration (days) & \\
\hline DENV-2 & P17 & $<0.4$ & $<0.4$ & $<0.4$ & $<0.4$ & $<0.4$ & 2.4 & 1.8 & $<0.4$ & 2 & \multirow{5}{*}{$3.2 \pm 0.6$} \\
\hline \multirow[t]{4}{*}{40247} & P37 & $<0.4$ & $<0.4$ & $<0.4$ & $<0.4$ & $<0.4$ & $<0.4$ & $<0.4$ & $<0.4$ & 0 & \\
\hline & $\mathrm{P} 47$ & $<0.4$ & $<0.4$ & $<0.4$ & 2.8 & 3.5 & 2.6 & 1.2 & $<0.4$ & 4 & \\
\hline & P57 & $<0.4$ & $<0.4$ & $<0.4$ & $<0.4$ & 2.6 & 3.6 & 2.1 & $<0.4$ & 3 & \\
\hline & O49 & $<0.4$ & $<0.4$ & $<0.4$ & $<0.4$ & 3.2 & 2.5 & $<0.4$ & $<0.4$ & 2 & \\
\hline DENV-2 & $\mathrm{P} 11$ & $<0.4$ & 1.2 & 0.9 & 1.8 & 2.4 & 2.9 & 2.9 & 1.9 & 7 & \multirow{5}{*}{$2.7 \pm 0.2$} \\
\hline \multirow[t]{4}{*}{$44 / 2$} & $\mathrm{P} 21$ & 0.9 & 0.9 & 2.5 & 2.3 & 2.4 & 2.0 & 1.6 & 1.4 & 8 & \\
\hline & $\mathrm{P} 25$ & 1.7 & 2.2 & 2.6 & 2.7 & 1.5 & $<0.4$ & $<0.4$ & $<0.4$ & 5 & \\
\hline & P33 & 1.4 & 2.2 & 2.6 & 2.2 & 1.2 & $<0.4$ & $<0.4$ & $<0.4$ & 5 & \\
\hline & O65 & 1.4 & 1.9 & 2.2 & 2.9 & 2.8 & 2.5 & 1.8 & 0.9 & 8 & \\
\hline
\end{tabular}


TABLE III

Wild-type dengue 3 viremia in rhesus monkeys

\begin{tabular}{|c|c|c|c|c|c|c|c|c|c|c|c|c|}
\hline \multirow[t]{2}{*}{ Virus } & \multirow[t]{2}{*}{ Monkey } & \multicolumn{10}{|c|}{ Viremia $\left(\log _{10}\right.$ PFU/ml) } & \multirow[b]{2}{*}{$\begin{array}{c}\text { Mean } \\
\text { peak titer }\end{array}$} \\
\hline & & 2 & 3 & 4 & 5 & 6 & 7 & 8 & 9 & 10 & $\begin{array}{c}\text { Duration } \\
\text { (days) }\end{array}$ & \\
\hline DENV-3 & 123 & $<0.4$ & $<0.4$ & $<0.4$ & 0.9 & 1.9 & 1.7 & 1.0 & $<0.4$ & $<0.4$ & 4 & \\
\hline \multirow[t]{4}{*}{ H87 } & E19 & 0.4 & 0.4 & 1.0 & 2.6 & 2.7 & 1.1 & $<0.4$ & $<0.4$ & $<0.4$ & 6 & \\
\hline & N20 & $<0.4$ & $<0.4$ & $<0.4$ & $<0.4$ & $<0.4$ & 1.5 & 0.9 & 1.4 & 1.1 & 4 & $2.0 \pm 0.5$ \\
\hline & $\mathrm{P} 24$ & $<0.4$ & $<0.4$ & 0.4 & 1.7 & 1.6 & 2.0 & 1.5 & $<0.4$ & $<0.4$ & 5 & \\
\hline & P44 & $<0.4$ & $<0.4$ & $<0.4$ & 1.7 & 1.6 & 1.7 & $<0.4$ & $<0.4$ & $<0.4$ & 3 & \\
\hline
\end{tabular}

mia for the 3 monkeys that received the DENV-3 74886 virus by real-time RT-PCR according to the methodology described by Poersch et al. (2005). Monkey N44 showed 4 days of viremia whereas monkey $\mathrm{O} 48$ presented 1 day only and monkey M50 was not viremic by this assay either. The mean titer was $2.2 \log _{10} \mathrm{PFU} / \mathrm{ml}$ with a mean duration of 1.7 days/animal.

\section{DISCUSSION}

DV, with its four serotypes, have spread throughout the tropics and there is an increasing disease severity (DHF/DSS). Despite decades of research there are no vaccines licensed and disease control has relied on reducing mosquito vector density.

Preclinical testing of dengue vaccine candidates has been usually carried out initially in a mouse model and later in a nonhuman primate model. In both cases the neutralizing antibody response is the main end-point for immunogenicity. Protection against encephalitis or viremia reflects efficacy in the mouse and monkey models, respectively. In our efforts to develop a live attenuated dengue vaccine based on chimeric yellow fever 17D viruses (Caufour et al. 2001, Mateu et al. 2007) and in the unavailability of wild type dengue viruses well characterized for viremia in rhesus monkeys, we have aimed at establishing a nonhuman primate model to test the protective capability of the recombinant viruses.

One basic aspect for selecting a virus for the challenge was its ability to plaque in Vero cells so that its viremia in monkey serum could be easily assayed. It can be argued that Vero cell plaque efficiency may differ among strains or serotypes and that the assays could have detected only a subpopulation not represented in the inoculum. In this regard the use of nucleic acid amplification procedures such as real-time PCR (Houng et al. 2001, Poersch et al. 2005) has been established for the quantification of DEN viral RNA in biological samples. Although it is true that measuring RNA copies may better reflect ongoing viral replication and would, therefore, be more appropriate to assess protective efficacy, the plaque assay reflects fully functional viral particles and not RNA molecules alone. Moreover, real-time RTPCR assays on RNA extracted from monkey serum have been shown to be sensitive to serum inhibitors and thereby may lead to lower estimates of infectivity (Al Soud et al. 2000). Considering that the well-standardized plaque assay was applicable to all viruses (except for DENV-3 74886), it became the method of choice for viremia determination in sera of monkeys inoculated with the selected wild type DEN viruses. Additionally, we have used real-time RT-PCR to assay the viremia that resulted from inoculation of DENV-3 74886 into rhesus monkeys, despite its limitations in sensitivity when monkey serum is used.

The DENV-1 60305 is a Vero-cell adapted virus that consistently plaques in this cell line. It caused limited viremia in all 5 recipient animals. In contrast the 16007/ $\mathrm{V}$ virus, which also plaques well in Vero cells had a better infectivity profile for rhesus monkeys causing viremia almost 10-fold higher with much longer duration. Viremia and seroconversion in all recipient animals after inoculation of rhesus monkeys with DENV-1 16007 has been reported (Halstead et al. 1973a, Halstead \& Marchette 2003). Halstead et al. (1973a) observed that most rhesus monkeys receiving the 16007 virus had viremias for 5-6 days a result which is similar to ours. The reported range (0.6 to $4.2 \log _{10} \mathrm{PFU} / \mathrm{ml}$ ) was different from what we observed (0.4-2.4 $\log _{10} \mathrm{PFU} / \mathrm{ml}$ ) what may be due to the cell system used for the plaque assay. DENV-1 16007/V was chosen as the challenge virus given its consistency in producing viremias similar in titer and duration in all rhesus monkeys. In fact, we have recently used this virus to challenge rhesus monkeys which were previously immunized with a chimeric YF 17D-DEN 1 virus (data not shown). It was also used by Butrapet et al. (2002) to show protection of rhesus monkeys after immunization with chimeric DEN 2 PDK53/DEN 1 virus.

The DEN 240247 virus yielded significant viremias in $80 \%$ of the animals (range $1.2-3.6 \log _{10} \mathrm{PFU} / \mathrm{ml}$ ), which were rather short-lived. In contrast the DENV-2 44/2 caused viremia in all animals for longer periods although with a somewhat lower mean peak titer. Not withstanding, given the consistency of 44/2 virus in generating measurable and durable viremias we reasoned it would be the most appropriate virus to be used for challenging after immunization with any candidate vaccine.

The DENV-3 H87 strain was selected based on its ability to induce viremia in all animals with significant mean peak titer and duration as compared to the inability of the DENV-3 16562 and 74886 to produce significant viremia. The 16562 virus also failed to produce viremia in cynomolgus monkeys but did induce seroconversion (Angsubhakorn et al. 1994). An earlier study showed the DEN 316562 virus was capable of causing viremia in rhesus monkeys with onset between the 3rd and 6th days p.i. although with rather short duration (Halstead et al. 1973a). With regard to the DENV-3 74886 virus, a Brazilian isolate, no previous data on its 
TABLE IV

Comparative viremia of wild-type dengue viruses in rhesus monkeys

\begin{tabular}{lccc}
\hline Virus strain & Mean peak titer & Mean duration & Reference \\
\hline D1-PUO359 & $3.4 \pm 0.3$ & $7 \pm 0.8$ & Guirakhoo et al. \\
D2-S16803PGMK 4 & $4.3 \pm 0.8$ & $6.5 \pm 1.7$ & 2002 \\
D3-PaH881 & $2.9 \pm 0.2$ & $5 \pm 0.8$ & \\
D4-1228 & $2.6 \pm 0.1$ & $6.6 \pm 1.5$ & Guirakhoo et al. \\
D1-West Pacific 74 & $3.2 \pm 0.2$ & $4.5 \pm 0.8$ & 2004 \\
D2-S16803PDK10 & $2.5 \pm 0.9$ & $4.3 \pm 0.5$ & Eckels et al. \\
D3-CH53489 & $2.2 \pm 0.4$ & $5.3 \pm 1.3$ & 2003 \\
D4-341750 & $3.2 \pm 0.3$ & 6.8 & 5 \\
D1-45AZ & NA & 3 & This paper \\
D2-S16803 & NA & 4.7 & 7 \\
D3-CH53489 & NA & $6.6 \pm 1.5$ & \\
D4-341750 & NA & $4.4 \pm 1.1$ & \\
D1-16007/V & $1.9 \pm 0.6$ & $2.7 \pm 0.3$ & \\
D2-44/2 & $2.0 \pm 0.5$ & & \\
D3-H87 & & & \\
\hline
\end{tabular}

NA: not available.

infectivity for rhesus monkeys was available but realtime RT-PCR showed that it did cause very limited viremia in 2 out of 3 animals. The viremia was also in the order of $2.0 \log _{10} \mathrm{PFU} / \mathrm{ml}$ but was shorter than that observed for DENV-3 H87 virus. As noted for DEN 3 16562 virus all monkeys inoculated with DENV-3 74886 seroconverted (data not shown).

A comparison of viremia levels and duration for different sets of viruses used for challenging rhesus monkeys is shown in Table IV. The set of viruses we chose for challenge studies in rhesus macaques are similar to the other sets used by Guirakhoo et al. $(2002,2004)$ and Eckels et al. (2003) as far as duration is concerned but in general they tend to produce lower viremias. However, we believe these titers are high enough and last time sufficient for a clear assessment of protective immunity as we have recently demonstrated after immunization of rhesus monkeys with chimeric 17D-DEN 2 viruses (Galler et al. 2005).

It can be argued that too many passages in cultured cells might have brought about phenotypic alterations in the working seed viruses and these would not reflect their original pathogenic potential found in nature. However, no monkey model has been shown to reflect the severe forms of the disease except in a couple rhesus monkeys out of more than a hundred examined after secondary DENV infection (Halstead et al. 1973a,b). There may also be an individual contribution to disease severity in addition to the viral genotype. Immunopathological events that may lead to severe outcome in humans (Green \& Rothman 2006) do not seem to occur in monkeys despite their susceptibility to dengue viruses. Therefore, immunity elicited by any candidate vaccine should provide protection of monkeys against viremia by each of the selected viruses as a pre-requisite for clinical trials.

\section{ACKNOWLEDGMENTS}

To Instituto de Tecnologia em Imunobiológicos, BioManguinhos-Fiocruz for the continuous support to this work. To Dr Antônio M Marinho, Centro de Criação de Animais de Laboratório-Fiocruz) for providing the rhesus monkeys used in all experiments. To the technical assistance of José M da Silva, Idevaldo I Ferreira, Mauro F da Silva, and Edney do Monte.

\section{REFERENCES}

Al-Soud A, Jönsson LJ, Rädström P 2000. Identification and characterization of immunoglobulin $\mathrm{G}$ in blood as a major inhibitor of diagnostic PCR. J Clin Microbiol 38: 345-350.

Angsubhakorn S, Yoksan S, Pradermwong A, Nitatpattana N, Sahaphong S, Bhamarapravati N 1994. Dengue-3 (16562) PGMK 33 vaccine: neurovirulence, viremia and immune responses in Macaca fascicularis. Southeast Asian J Trop Med Public Health 25: 554-559.

Bhamarapravati N, Yoksan S 2000. Live attenuated tetravalent dengue vaccine. Vaccine 18: 44-47.

Bente DA, Rico-Hesse R 2006. Models of dengue virus infection. Drug Discovery Today 3: 97-103.

Blaney Jr JE, Matro JM, Murphy BR, Whitehead SS 2005. Recombinant, live-attenuated tetravalent dengue virus vaccine formulations induce a balanced, broad, and protective neutralizing antibody response against each of the four serotypes in rhesus monkeys. J Virol 79: 5516-5528.

Butrapet S, Rabablert J, Angsubhakorn S, Wiriyarat W, Huang C, Kinney R, Punyim S, Bhamarapravati N 2002. Chimeric dengue type $2 /$ type 1 viruses induce immune responses in cynomolgus monkeys. Southeast Asian J Trop Med Public Health 33: 589-599.

Caufour PS, Motta MC, Yamamura AM, Vazquez S, Ferreira, II, Jabor AV, Bonaldo MC, Freire MS, Galler R 2001. Construction, characterization and immunogenicity of recombinant yellow fever 17D-dengue type 2 viruses. Virus Res 79: 1-14.

De Simone TS, Nogueira RM, Araujo ES, Guimarães FR, Santos FB, Schatzmayr HG, Souza RV, Teixeira Filho G, Miagostovich MP 2004. Dengue virus surveillance: the co-circulation of DENV-1, DENV-2 and DENV-3 in the State of Rio de Janeiro, Brazil. Trans R Soc Trop Med Hyg 98: 553-562.

Eckels KH, Dubois DR, Putnak R, Vaughn DW, Innis BL, Henchal EA, Hoke Jr CH 2003. Modification of dengue virus strains by passage in primary dog kidney cells: preparation of candidate vaccines and immunization of monkeys. Am J Trop Med Hyg 69: 12-16. 
Edelman R, Wasserman SS, Bodison SA, Putnak RJ, Eckels KH, Tang D, Kanesa-Thasan N, Vaughn DW, Innis BL, Sun W 2003. Phase I trial of 16 formulations of a tetravalent liveattenuated dengue vaccine. Am J Trop Med Hyg 69: 48-60.

Galler R, Marchevsky RS, Caride E, Almeida LFC, Yamamura AMY, Jabor AV, Motta MCA, Bonaldo MC, Coutinho ESF, Freire MS 2005. Recombinant yellow fever 17D-dengue type 2 virus: attenuation and immunogenicity for rhesus monkeys. Braz J Med Biol Res 38: 1835-1846.

Gonçalvez AP, Escalante AA, Pujol FH, Ludert JE, Tovar D, Salas RA, Liprandi F 2002. Diversity and evolution of the envelope gene of dengue virus type 1. Virology 303: 110119.

Green S, Rothman A 2006. Immunopathological mechanisms in dengue and dengue hemorrhagic fever. Curr Opin Infect Dis 19: 429-436.

Gubler DJ 2004. The changing epidemiology of yellow fever and dengue, 1900 to 2003: full circle? Comp Immunol Microbiol Infect Dis 27: 319-330.

Guirakhoo F, Pugachev K, Arroyo J, Miller C, Zhang ZX, Weltzin R, Georgakopoulos K, Catalan J, Ocran S, Draper K, Monath TP2002. Viremia and immunogenicity in nonhuman primates of a tetravalent yellow Fever-dengue chimeric vaccine: genetic reconstructions, dose adjustment, and antibody responses against wild-type dengue virus isolates. Virology 298: 146-159.

Guirakhoo F, Pugachev K, Zhang Z, Myers G, Levenbook I, Draper K, Lang J, Ocran S, Mitchell F, Parsons M, Brown N, Brandler S, Fournier C, Barrere B, Rizvi F, Travassos A, Nichols R, Trent D, Monath T 2004. Safety and efficacy of chimeric yellow fever-dengue virus tetravalent vaccine formulations in nonhuman primates. J Virol 78: 4761-4775.

Halstead SB, Marchette NJ 2003. Biologic properties of dengue viruses following serial passage in primary dog kidney cells: studies at the University of Hawaii. Am J Trop Med Hyg 69: 5-11.

Halstead SB, Shotwell H, Casals J 1973a. Studies on the pathogenesis of dengue infection in monkeys. I. Clinical laboratory responses to primary infection. J Infect Dis 128: 7-14.

Halstead SB, Shotwell H, Casals J 1973b. Studies on the pathogenesis of dengue infection in monkeys. II. Clinical laboratory responses to heterologous infection. J Infect Dis 128: $15-22$.

Hammon WM, Rudnick A, Sather GE 1960. Viruses associated with epidemic hemorrhagic fevers of the Philippines and Thailand. Science 131: 1102-1103.

Hanley KA, Manlucu LR, Manipon GG, Hanson CT, Whitehead SS, Murphy BR, Blaney Jr JE 2004. Introduction of mutations into the non-structural genes or 3' untranslated region of an attenuated dengue virus type 4 vaccine candidate further decreases replication in rhesus monkeys while retaining protective immunity. Vaccine 22: 3440-3448.

Houng HH, Chen RC, Vaughn DW, Kanesa-thasan N 2001. Development of a fluorogenic RT-PCR system for quantitative identification of dengue virus serotypes 1-4 using conserved and serotype-specific 3' noncoding sequences. J Virol Meth 95: 19-32.

Mateu GP, Marchevsky RS, Liprandi F, Bonaldo MC, Coutinho ESF, Dieudonné M, Caride EC, Jabor AV, Freire MS, Galler
R 2007. Construction and biological properties of yellow fever 17D/ Dengue type 1 recombinant virus. Trans $R$ Soc Trop Med Hyg 101: 239-248.

Miagostovich MP, Sequeira PC, Dos Santos FB, Maia A, Nogueira RM, Schatzmayr HG, Harris E, Riley LW 2003. Molecular typing of dengue virus type 2 in Brazil. Rev Inst Med Trop São Paulo 45: 17-21.

Monath TP 2003. Yellow Fever Vaccine, WB Saunders, New York.

Monath TP, Heinz FX. 1996. Flaviviruses, Lippincott-Raven Publishers, Philadelphia, New York.

Nogueira RM, Zagner SM, Martins IS, Lampe E, Miagostovich MP, Schatzmayr HG 1991. Dengue haemorrhagic fever/dengue shock syndrome (DHF/DSS) caused by serotype 2 in Brazil. Mem Inst Oswaldo Cruz 86: 269.

Poersch CO, Pavoni DP, Queiroz MH, de Borba L, Goldenberg S, dos Santos CN, Krieger MA 2005. Dengue virus infections: comparison of methods for diagnosing the acute disease. J Clin Virol 32: 272-277.

Raviprakash K, Apt D, Brinkman A, Skinner C, Yang S, Dawes G, Ewing D, Wu SJ, Bass S, Punnonen J, Porter K 2006. A chimeric tetravalent dengue DNA vaccine elicits neutralizing antibody to all four virus serotypes in rhesus macaques. Virology 353: 166-173.

Raviprakash K, Ewing D, Simmons M, Porter KR, Jones TR, Hayes CG, Stout R, Murphy GS 2003. Needle-free Biojector injection of a dengue virus type 1 DNA vaccine with human immunostimulatory sequences and the GM-CSF gene increases immunogenicity and protection from virus challenge in Aotus monkeys. Virology 315: 345-352.

Rico-Hesse R 2003. Microevolution and virulence of dengue viruses. Adv Virus Res 59: 315-341.

Rico-Hesse R, Harrison LM, Salas RA, Tovar D, Nisalak A, Ramos C, Boshell J, de Mesa MT, Nogueira RM, da Rosa AT 1997. Origins of dengue type 2 viruses associated with increased pathogenicity in the Americas. Virology 230: 244-251.

Sabchareon A, Lang J, Chanthavanich P, Yoksan S, Forrat R, Attanath P, Sirivichayakul C, Pengsaa K, Pojjaroen-Anant C, Chambonneau L, Saluzzo JF, Bhamarapravati N 2004. Safety and immunogenicity of a three dose regimen of two tetravalent live-attenuated dengue vaccines in five- to twelveyear-old Thai children. Pediatr Infect Dis J 23: 99-109.

Sabchareon A, Lang J, Chanthavanich P, Yoksan S, Forrat R, Attanath P, Sirivichayakul C, Pengsaa K, Pojjaroen-Anant C, Chokejindachai W, Jagsudee A, Saluzzo JF, Bhamarapravati N 2002. Safety and immunogenicity of tetravalent live-attenuated dengue vaccines in Thai adult volunteers: role of serotype concentration, ratio, and multiple doses. Am J Trop Med Hyg 66: 264-272.

Sun W, Edelman R, Kanesa-Thasan N, Eckels KH, Putnak JR, King AD, Houng HS, Tang D, Scherer JM, Hoke Jr CH, Innis BL 2003. Vaccination of human volunteers with monovalent and tetravalent live-attenuated dengue vaccine candidates. Am J Trop Med Hyg 69: 24-31.

Sun W, Nisalak A, Gettayacamin M, Eckels KH, Putnak JR, Vaughn DW, Innis BL, Thomas SJ, Endy TP 2006. Protection of Rhesus monkeys against dengue virus challenge after tetravalent live attenuated dengue virus vaccination. J Infect Dis 193: 1658-1665. 